\title{
Possible polychaete tube worms from the Late Emsian (Early Devonian) of the Parana Basin, Brazil
}

Olev Vinn, Carolina Zabini, Gustavo Sene-Silva, Kalle Kirsimäe, and Lara Susan-Marcos

Acta Palaeontologica Polonica 61 (3), 2016: 627-632 doi:http://dx.doi.org/10.4202/app.00206.2015

Plastically deformed and silicified worm tubes from the Late Emsian (Early Devonian) of the Parana Basin are described herein as a new species and genus of annelid worms Annulitubus mutveii gen. et sp. nov. The tubes are straight and ornamented by smooth rings. Their microstructure is homogenous, which most likely is a diagenetic alteration. The characteristic early diagenetic compression of the tubes may point out to their original elastic organic tube wall. We cannot state it with full confidence but the most likely tube producers were tube-dwelling polychaete annelids, which were otherwise uncommon in the Paleozoic times.

Olev Vinn [olev.vinn@ut.ee] and Kalle Kirsimäe [kalle.kirsimae@ut.ee],

Department of Geology, University of Tartu, Ravila 14A, 50411, Tartu,

Estonia. Carolina Zabini [carolinazabini@utfpr.edu.br], Gustavo Sene-Silva [gustavosilva@utfpr.edu.br ], and Lara Susan-Marcos [larasusan18@gmail.com], Universidade Tecnológica Federal do Paraná, Estrada para Boa Esperança, Km 4. Dois Vizinhos, PR, 85660-000, Brazil.

This is an open-access article distributed under the terms of the Creative Commons Attribution License (for details please see creativecommons.org), which permits unrestricted use, distribution, and reproduction in any medium, provided the original author and source are credited.

Far Full text $(481.1 \mathrm{kB})$ ।

Pof Supplementary file $(1,395.5 \mathrm{kB})$ 